\title{
Incidental Duties of the College Librarian
}

$\mathrm{T}_{\mathrm{b}}$

HIS ARTICLE originated in a suggestion by the editors of College and Research Libraries. The author, after an unrewarding search of the available literature, decided to fall back on the time-honored device of picking his colleagues' brains and sent fifty-nine letters to representative librarians of college and university libraries asking them to outline their own incidental duties. The assignment evidently struck a responsive chord. Fifty-two librarians replied, some at great length.

\section{Points of View on Incidental Duties-Affirmative}

The question will at once be raised (and very properly): "Are any of a librarian's duties 'incidental'?" On this point Willis $\mathrm{H}$. Kerr, director of the Claremont Colleges Library, writes: "Your question is interesting. How incidental are the incidental duties of a college librarian? Far from believing that they interfere with his proper job, I believe the 'incidental' jobs which come his waty reveal how far his library is geared into the institution and give him countless strategic opportunities to feel the institutional pulse and to know its innermost economic and academic and research trends, yearnings, beliefs, principles, and achievements (or sometimes the lack of them). I believe they are almost his largest opportunity for applied librarianship and scholarship." And Charles E. Rush, director of the library of the University of North Carolina, has this to say on the same question: "By glancing backward, I can observe that some of the incidental duties of a librarian are frequently more important in specific results than some of the more basic ones. 'Incidental' seems to me to be the wrong word for jobs which may be more important than casual accidents, possible happenings, mere 'happenstances.' 'Contingent' might be better, if it includes the librarian's constructive performance in these extraoffice duties. I'm thinking of these opportunities which can unlock the door and open the windows of the library, not only for the campus to come in, but also for the librarian to get out. More college librarians shut themselves in than there are those who let themselves out purposefully. You will find lively libraries where the latter is practiced, no matter what the doubting Thomases say concerning loss of professional time. In our line, he who sticks precisely to his last mends few shoes and neglects his own."

A. F. Kuhlman, director, Joint University Libraries, Nashville, Tenn., adds: "I am well aware of what you call incidental duties. I question, however, whether they should be thought of as incidental. Some of these days when we get our relationship properly established with the administrative and executive officers of colleges and universities, and when the teaching functions of the library are better understood by faculties and instructors in our schools, I think that there will be a great many relationships that we will have to maintain that will be considered fundamental." 


\section{Points of View-Negative}

It will be observed that the librarians quoted above belong to the school of thought which welcomes incidental duties. There is another school of thought which takes an opposite point of view. Robert Bingham Downs, director of the University of Illinois Library, probably speaks for a number of librarians when he says: "It has always been my policy to avoid numerous tie-ups which do not have a direct relationship to the library because I am convinced that such undertakings interfere with one's regular job and the library is likely to play a secondary role. Of course, I realize that general activities outside the library may give the librarian some interesting contacts and connections which will prove useful to him in the administration of the library. Unless such activities are limited, however, to fundamental committees and faculty groups, the day is likely to be spent on matters which have little or no relation to one's primary responsibilities. After all, there are only so many hours in a day."

This point of view is perhaps representative of the largest university libraries. Keyes D. Metcalf, director, Harvard University Library, comments that: "The larger the institution and the more complicated the administrative problem in which the librarian is involved, the less likely he is to take part in faculty committee work." To which Harold L. Leupp, recently retired librarian, University of California, appends: "At the University of California the librarian is a member of various committees, both faculty and administrative, which have to do with library matters; but that is all. I cannot say that I have found any need for extracurricular activities to occupy my spare time. The administration of the library is enough of a job to occupy one man's time."

\section{Points of View-Resignation}

Most librarians probably occupy a middle ground in this dispute and accept the incidental duties that come their way as inescapable. Many will doubtless feel for Hazel E. Armstrong, librarian, Indiana State Teachers College, when she says: "For the most part these incidental duties are pleasant and also inevitable unless one shuts oneself up. But I would like to visit my dentist without coming away with a commission to help with his family tree." Or with Mary S. Buffum, librarian, Texas State College for Women, who writes: "The question is, how can one person find time to do all of these things in addition to the daily routine which must be attended to?"

\section{The Extent of Participation}

Even when a librarian is "sold" on the importance of incidental duties, the time actually devoted to such duties may vary widely. The practice of three well-known librarians may be cited. Charles F. Gosnell, former librarian of Queens College, writes: "I have never estimated exactly how much time I spend on these incidental duties'; it is probably about 15 per cent. About half, or 7 per cent, is devoted to personnel and budget, and building, and, because it is chiefly in presenting library matters, may not count as 'incidental.' This would leave approximately 8 per cent for other than immediate library business." Ralph Eugene Ellsworth writes of his experience at the University of Colorado: "I would judge that I spent a third of my time on committee work." And G. Flint Purdy, librarian, Wayne University, says: "By way of summary, I believe that I spend something less than half of my time in administering the affairs of the university library, and the majority of the balance in extralibrary university affairs." 
Errett Weir McDiarmid, librarian, University of Minnesota, notes that many of these incidental duties may be carried out quite informally outside of "office hours": "Much incidental business is conducted here at our Campus Club where a large portion of our faculty lunch. Committee meetings are frequently held at noon. Informal groups get together at various tables, and in general much university business is transacted there."

A number of librarians call attention to the fact that not only the librarian but the members of his staff are frequently called upon to perform various incidental duties. This is true to a limited extent even in the largest universities, such as Harvard. Iowa State College, Howard University, and the Woman's College of the University of North Carolina may be mentioned as institutions with a high degree of staff participation. Miss Barcus Tichenor, librarian, Ball State Teachers College, Muncie, Ind., writes of her institution that: "All of the regular members of the library staff are supposed to attend faculty meetings and have full voting power. Each of us is on at least one faculty committee."

\section{Qualifying Considerations}

The extent to which a librarian participates in extralibrary affairs seems to depend upon a number of factors. Some of the most important are: the size of the institution, the type of institution, the personality of the librarian, the history and traditions of the institution. Ermine Stone, librarian, Sarah Lawrence College, comments on some of these factors: "It seems to me that the extracurricular duties that devolve upon the librarian vary according to several conditions, but are principally determined by the type of the institution and by the personal characteristics and skills of the person involved. One acquires assignments because of length of tenure and knowledge of the local situation, even if these assignments are not related to the library. Obviously the librarian who is tactful and a good mingler is going to find himself doing a great many things that would not come his way if he were shy and retiring."

Mr. Rush adds that: "For some reason, age and length of service should be figured in. Seemingly, these outside-of-the-library activities, services, relationships, friendships -all indicative of what the library freely offers-are more important for the librarian whose professional years are few and period of tenure is short. This, of course, is particularly true in any new administration of a slumbering library. On the other hand, a library that for forty years has extended itself into all phases of college life, through the personal and professional services of its librarians, eventually gains a high local reputation which results in the natural inclusion of librarianship in important general activities, thus releasing the present incumbent from those which may seem onerous.

"The last sentence applies to this library. If you seek a perfect example of the importance and effect of campus activities on library progress, check carefully the record of Dr. Wilson at the University of North Carolina from I90I-32, as recorded in my contribution to Louis Round Wilson issued by the University of Chicago Press."

B. Lamar Johnson, dean of instruction and librarian, Stephens College, points out that in an institution like Stephens, where the library is really the center of the teaching process, duties such as committee work, teaching, sponsoring student organizations, and advising individual students, which might elsewhere be thought of as incidental, become fundamental.

What Are the Incidental Duties of a College or University Librarian?

Donald Coney, formerly librarian of the 
University of Texas and now of California, writes: "I think you would do well to try to distinguish between duties which are clearly incidental, and those which are nonlibrary but are important to the functioning of the library at a suitably high level in the college or university. In my own case, through membership in the groups responsible for the Institute of LatinAmerican Studies and the Littlefield Fund for Southern History, it is possible for me to see that funds are sometimes used for the purchase of library materials, and that wherever the library may be involved its interests are taken into account. This latter statement applies, of course, to the activities of any group with which the librarian is associated. I should certainly not be inclined to regard membership in the several committees, such as job classification, etc., as incidental to the work of the librarian. These committees usually are carrying on activities that have clear implications with respect to the library, and the library is fortunate to be represented."

With this advice in mind the author will attempt to list the incidental duties most commonly performed by the librarians of colleges and universities-listing them, under each heading, in what seems to be their order of importance. Any such order is of course debatable. If any particular duty seems to a reader to be either too fundamental or too incidental for inclusion here, the author can only plead that it is actually performed, and is considered incidental, by the practicing librarians who contributed to this symposium.

\section{Duties to the Library as a Part of the Institution}

\section{Committee Assignments}

In most colleges and universities a large part of the administrative function is vested in the various faculty committees. They are particularly concerned with the formulation of policies, with planning, and with supervision. It is worth a great deal to a library to be represented on at least the more important of these "steering committees."

On this topic Charles Harvey Brown, librarian, Iowa State College, writes: "It is, of course, a great help to the library as well as to the college to have members of the library staff represented on college committees. In many cases librarians are valuable on committees because they are not tied up with departments and are free from departmental influences and prejudices. On the other hand, membership is not a right that can be claimed. Members of the staff will naturally gravitate to such committees as their personalities and standings justify."

A number of college and university librarians take a very active part in the administration of their respective institutions, through membership on faculty committees. Three instances will be cited. John Richmond Russell, librarian, University of Rochester, reports: "I serve as secretary to the university library committee. For two years I served as chairman of the university lecture committee. I am now secretary of the university committee on honorary degrees and also a member of the university council, which is the faculty policy-making body for the university as a whole. I am a member of the bookstore committee, which supervises the operations of the university bookstore. This past winter I served on the postwar curriculum com- 
mittee which is one of the committees set up to study postwar education."

Walter G. Daniel, librarian, Howard University, writes: "Among the responsibilities which I currently share are the following: (I) chairman of the faculty committee on student organizations and activities, which serves as an intermediary group between faculty and students and gives general direction to student matters; (2) chairman of the university forum committee; (3) chairman of the special committee on education and national defense; (4) by virtue of the office of librarian, I serve on the council of deans and administrative officers, university council, committee on public functions, library committee, and the freshman-sophomore advisory board."

And finally, Charles F. Gosnell, formerly librarian, Queens College: "I was a member of the curriculum committee for the first four years of the college and secretary of the committee for one year. I have, from the beginning, been a member of the committee on personnel and budget, which passes on recommendations for appointment and promotion, and on budget. At present I am chairman of the committee on student publications and chairman of the library building committee. I am an elected member of the legislative committee and a delegate to the legislative conference of the city colleges."

\section{Library Committee}

The vital importance to the library of representation on this committee is too obvious to require comment. In most institutions, the librarian is a member of the committee as a matter of course. Frequently he is chairman or secretary. If a college or university has, in addition, an auxiliary committee on archives, charged with collecting and preserving the records of the institution, the librarian should be a member of this related committee as well.

\section{Council}

Approximately half of the fifty-two librarians contributing to this survey reported representation on the council, board, or cabinet charged with advising the president and with aiding him in the tasks of policymaking and general administration. Necessarily, the decisions arrived at in such a council affect the work of the library at many points. If membership on the library committee is of first importance to the library, it is almost equally important that the library be represented on the administrative council. Further, if the librarian is to be recognized as an administrative official, with a rank comparable to that of a dean, he should have the opportunity and the responsibility of participating in the deliberations of the executive council. Membership on other committees concerned with general administration can pay large dividends to the library, particularly in the case of those having to do with personnel and budget.

\section{Instruction and Research}

Another committee whose work closely affects the library is that of the committee on curriculum. To quote Earl Gregg Swem, formerly librarian of the College of William and Mary: "The college librarian should be an active member or an associate member of the curriculum committee of the college faculty. Otherwise, he will discover that new courses have been presented in the catalog on most unusual subjects with hardly a book on the subject in the library." Lois E. Engleman, former librarian, Colby Junior College, adds: "A most stimulating experience is that of serving on the faculty committee on curriculum and instruction. I found activities and discussion of this committee of great value in directing the development of the book and periodical collections to meet the needs of new courses, in altering systems of 
reserves to solve definite instructional problems, and in determining policies of purchasing duplicate copies of background titles of survey courses."

It is also an advantage to the library to be represented on any committee having to do with research. As already pointed out by Mr. Coney, these committees frequently have at their disposal funds which may be expended for the purchase of library materials, and the librarian, with no departmental axe to grind, has a great deal to contribute as impartial arbiter. In a number of instances librarians serve as chairmen of these research committees.

\section{Publications}

In many institutions the librarian is a member of the publications or university press committee. Mr. Swem writes with regard to this matter: "The librarian should be on the publications committee of the college in order to guide wayward faculty and administrative editors in maintaining consistent series titles. The librarian should have some connection also with the mailing and distribution of all publications of the college. As a member of such a committee he should use his influence toward one central mailing office of distribution. This affects the library very closely'on account of exchanges."

The right sort of librarian, as a man of wide interests, with some training and experience as bibliographer, editor, and publicist, has much to contribute to a committee concerned with university publications, and it is of considerable value to the library that it be fully informed in this field. If the library sponsors publications of its own, membership on this committee assumes added importance.

\section{Minor Committee Assignments}

The committees already named are probably the most important ones from the point of view of the library. But there are a number of others whose work affects the library in varying degrees. Several instances will be given, with no attempt at any particular order.

At Mount Holyoke, Flora Belle Ludington was chairman of the Central Fund Raising Committee. This committee is made up of trustees, alumnæ, and administrative officers. It discusses and approves projects for which funds are being sought but does not have the responsibility for the actual soliciting of funds.

Many librarians report membership on a special lectures, public affairs, or auditorium events committee. Such membership, reports Mr. Swem, makes it possible for the librarian "to know what lectures are to come and what displays of books should be prepared."

In a number of instances, where the librarian serves on the university press committee, he is also a member of the committee which supervises the university bookstore. There is a fairly obvious relationship between the library and the bookstore as common purveyors to the university public. The library may employ the bookstore as its purchasing agent. Whether or not this is the case, the manager of the bookstore will be a useful source of information concerning discounts and the book trade in general. And certainly the librarian will be concerned that students acquire the habit of owning books.

At the Georgia School of Technology, the librarian, Mrs. James Henley Crosland, is a member of the committee on instructions for the preparation of master's theses. At William and Mary the librarian performs a similar function, and Mr. Swem says: "I believe that the college librarian should be on the degree committee for masters and doctors and be present at oral examinations; he should have a few questions to propose to candidates to see whether they have the least idea of current trade 
bibliographies and of some of the great bibliographical projects of the last fifty years. If this were done regularly we would have fewer doctors innocent of bibliographical attainment outside of their own department."

At a number of institutions the library, for obvious reasons, is represented on the postwar planning committee. In other instances the library's interest in radio and in audio-visual programs is recognized. Membership on the college building committee is occasionally reported.

- This tabulation of committee assignments does not pretend to be definitive. There are many other committees to which librarians may and do belong. But of those reported to the compiler, the balance either fall under categories already mentioned, or they seem to lack a connection with the duties of a librarian, whatever they may contribute in the way of personal rewards.

\section{Faculty Relations}

Few will deny that, for full success, the librarian of a college or university must have the respect and support of his faculty colleagues. A librarian who holds himself aloof, takes no part in faculty activities, and makes few friends, will have a hard row to hoe and a lonely one. The centrality of the librarian's position in an institution makes the matter one of especial importance. He should be widely and favorably known to his fellows and familiar with their needs and interests, if he is to serve them adequately and win their cooperation.

The efficient performance of one's duties, evidence of scholarship, and a wide knowledge of books will win respect in any situation. In a small institution friendliness, an interest in one's fellow man, and a willingness to serve will do the rest.

In a large university, with a teaching staff numbering hundreds, the problem is more difficult. Many worth-while relationships will come about through the performance of one's daily chores, others will be established in committee rooms and in one's offthe-campus social life; but the process of "winning friends and influencing people" will be accelerated if the librarian becomes a member of the faculty club and other similar organizations and takes an active part in their work. Many librarians report service as members and as officers of faculty clubs and groups.

\section{Student Relations}

In the smaller colleges and universities the librarian has many opportunities within the library itself for direct contact with individual students and with student groups. In the larger universities the burden of administrative work interferes and this opportunity passes largely to the subordinate members of the staff.

Contact with student groups and with individual students may take other, extralibrary forms. The librarian may serve on the student activities committee, or on other faculty boards and committees having to do with student affairs. He may act as adviser to student publications. He may concern himself with other student activities, such as debating. He may function as sponsor and counselor of student clubs and, finally, he may share with the faculty the task of advising individual students.

It is a moot question how far a librarian can and should go in this direction. A good deal may be done even in a large institution if the library staff as a whole shares the burden and the opportunity. At Harvard, for example, Mr. Metcalf writes that members of his staff have, from time to time, served as student advisers.

With regard to the advising of individual students William Ditto Lewis, librarian, University of Delaware, writes: "In an institution where the librarian is not desig- 
nated as student adviser, he has a certain edge on his 'designated' colleagues. His interdepartmental status gives, or can give, him the advantage of steering an occasional student into fields in which said student has felt little or no interest and occasionally into fields not represented in the curriculum at all. In a university where there is little nonacademic contact between student and faculty, the eccentricity of the librarian's position gives him an occasional opportunity to function as guide, counselor, and friend. The librarian with better mixing qualities could develop them far more and ought to extend this to the faculty as well as to students, and he might eventually do much toward breaking down the unfortunate philosophy behind student-faculty reticence."

More than one librarian has found that work with some particular student group was well worth the time and effort expended. Wallace Van Jackson, librarian, Atlanta University, writes of his incidental duties while librarian of Virginia Union University: "Of all these duties at Virginia Union, the task of debate coach was the most stimulating and helpful. Students put something into extracurricular activities which they withhold from regular class work. The opportunity to work with those young men and young women made me a better library administrator and certainly showed me much about student needs in books and teaching materials. Throughout my library experience I have been counselor to individual students, especially in matters of vocational choice, but the work with the debate and literary group was much richer. As a result of work with these young persons I have received the thrill that comes to teachers when a student accomplishes something after leaving school."

\section{Training and Teaching}

The last quotation introduces us indirect- ly to yet another category of peripheral duties. For convenience they may be grouped as follows: instruction in the use of the library, training of apprentices and student assistants, the teaching of courses in library science, the counseling of prospective librarians, and speaking before campus groups on topics relating to books and libraries. Probably every librarian does something along these lines, more or less formally, and to greater or less degree.

The training of potential members of the library staff through apprentice classes has diminished in importance with the rise of library schools, but has by no means passed out of the picture. Mr. Jackson is worth quoting again on this topic: "A task which was not so 'incidental' was the training of apprentices for our library at Virginia Union. I probably came closer to shaping the lives of these students than at any other time. This was in the pioneer days of Negro school libraries, and members of our apprentice class became the first full-time school librarians in Virginia. Three or four went to library school and became college librarians. One succeeded me as acting librarian of Virginia Union."

\section{Miscellany}

Anyone who attempts to draw up a classification of the manifold duties of librarians will probably find that he has left over a number of items which refuse to fit into his pigeonholes.

For example James A. McMillen, formerly director of libraries at Louisiana State University, stated: "Not the least important incidental duty is to show individuals through your library and give them a fair idea of just what you are about. This is especially important when it comes to showing delegates to important educational conferences through 'your shop.' This adds to goodwill and leaves a proper flavor to their memory of their trip. Occa- 
sional investigators must be given special attention and not be allowed to leave with unsatisfied curiosity about your library."

Mr. Swem writes of William and Mary: "On account of the age of the college, its connection with American early history, and being in Williamsburg, the college library and its staff have been called on for rather unusual duties. I have developed the library to meet these demands. I may add that this work has brought many friends and gifts."

Harriet Dorothea McPherson, librarian, Smith College, reports a number of unusual duties made necessary by the out-of-theordinary character of the library building, with its very large number of faculty offices and seminar rooms, its chapel, and its faculty tea room.

In the above listing the compiler has omitted many items reported to him. Those omitted include membership on committees having no apparent connection with the library, the teaching of other than library science courses, editorial duties in connection with particular journals, membership in various learned societies, the holding of such offices as registrar, dean of women, director of extension activities, or college marshall, activities in connection with commencement, dormitory duties, the coaching of athletic teams, and varied responsibilities having to do with the college museum, art gallery, or musical society.

Any one of the above activities may be defended as valuable and necessary in a given situation, but for the purposes of this article they seem to lie too far afield to merit classification among the duties of a librarian.

\section{Duties to the Community}

Library service to a municipality is usually thought of as the prerogative of the public library, but all college and university libraries probably serve at least a few individuals in the community who have no connection with their institution, particularly in the smaller college towns where the public library is not equipped to meet the demands of special students.

This is a particular problem of Negro colleges and universities in Southern towns where service to Negroes may not be available from the public library. LeMoyne College, Memphis, and Wilberforce University, Wilberforce, Ohio, may be taken as representative. Francis W. Allen, former librarian of LeMoyne College, writes that: "Our largest item outside regular college library functions consists of building up library service for the community. As you know, library coverage for Negroes in the South is not too good. LeMoyne is attempting to do something about that in our own area, particularly our own immediate community in South Memphis. We have at present established three subsidiary libraries: one, a children's library in our own building; second, a school library in a neighboring private elementary school; and, third, a community library in a socially-conscious Negro church." At Wilberforce, the librarian, Mollie E. Dunlap, reports that the library staff administers a branch of the county library which is housed in the university library building.

"Acting as advisor to collectors of local literature," "answering requests from the technical book department of a large department store for advice on technical books," "serving as general consultant on library matters to the community," are some of the other ways in which a college librarian may serve the community at large. Hazel E. Armstrong, librarian, Indiana 
State Teachers College, tells us that a college librarian must be prepared to "give advice on books as gifts and where and how to purchase, to anyone at any time, even on street corners, buses, etc.; carry back to the library from lunch, a shopping expedition, or any casual meeting all kinds of suggestions and requests; and listen to sometimes endless conversations of patrons about books and book reviews."
Several university librarians report active membership in community social and cultural clubs as among their incidental duties. This activity is reminiscent of the public library field, where it is, of course, carried to much greater lengths. One college librarian, formerly in public library work, reports resigning from more than twenty civic and educational organizations on leaving his last post.

\section{Duties to One's Profession}

Most librarians, in whatever type of work they are engaged, would probably admit as being among their duties the various activities designed to forward the profession of librarianship and the interests of libraries in general. Active participation in local, state, and national library organizations, contributions to professional literature, the presenting of library interests before government bodies and educational associations, aiding in library projects of more than local significance, "advice to newcomers in the field," cooperating with other libraries, are some of the forms which service to one's profession may take.

Every librarian can make a contribution in this field according to his abilities and opportunities. Some librarians carry a very heavy load. In extreme cases there is danger that ambition or overzealousness may lead a librarian to devote too much time to these activities, to the neglect of his primary responsibility. The average librarian, however, is far more likely to go to the other extreme and, in an undue concentration on his immediate problems, neglect this opportunity for wider service.

\section{Summary}

The consensus would seem to be that the librarian of a college or university, apart from his "regular duties," will profit through membership on those committees whose proceedings affect the library most closely-chiefly, the library committee itself, the executive council, the curriculum committee, and the committee on publications. He will be well advised to do all he can to establish cordial relations with his faculty colleagues. Anything that he or his staff can achieve toward a wider acquaintance with student needs and interests should prove worth while. He will hardly escape some duties connected with training and teaching. He may be called upon to give a measure of service to the community outside the walls, and he should join his fellows in furthering the profession he represents.

This is a formidable list, a list well calculated to appal the stoutest-hearted beginner; but the experienced librarian knows that many things come to be taken in one's stride which once seemed impossible of accomplishment. Certainly such a list should demonstrate to the skeptical how varied and interesting our calling can be.

Each librarian must decide for himself which activities will pay the greatest dividends in his particular situation, how far he can go in any given direction in justice to his other responsibilities, and concentrate his time and energy accordingly, sharing his duties with the staff wherever possible. 